\title{
Lamin-binding Proteins
}

\author{
Katherine L. Wilson ${ }^{1}$ and Roland Foisner ${ }^{2}$ \\ ${ }^{1}$ Department of Cell Biology, Johns Hopkins University School of Medicine, Baltimore, Maryland 21205 \\ ${ }^{2}$ Max F. Perutz Laboratories, Department of Medical Biochemistry, Medical University of Vienna, Vienna 1030 \\ Correspondence: roland.foisner@meduniwien.ac.at
}

A- and B-type lamins are the major intermediate filaments of the nucleus. Lamins engage in a plethora of stable and transient interactions, near the inner nuclear membrane and throughout the nucleus. Lamin-binding proteins serve an amazingly diverse range of functions. Numerous inner-membrane proteins help anchor lamin filaments to the nuclear envelope, serving as part of the nuclear "lamina" network that is essential for nuclear architecture and integrity. Certain lamin-binding proteins of the inner membrane bind partners in the outer membrane and mechanically link lamins to the cytoskeleton. Inside the nucleus, lamin-binding proteins appear to serve as the "adaptors" by which the lamina organizes chromatin, influences gene expression and epigenetic regulation, and modulates signaling pathways. Transient interactions of lamins with key components of the transcription and replication machinery may provide an additional level of regulation or support to these essential events.

$T^{\text {he }}$ he eukaryotic cell nucleus is a complex membrane-bounded organelle that houses, organizes, and regulates the genome. The nucleus is structurally organized into functional domains, one of which is the nuclear envelope (NE). The NE has two concentric membranes, named the "inner" and "outer" nuclear membranes (INM and ONM, respectively). These membranes are separated by a $30-50 \mathrm{~nm}$ lumen, and fuse to form holes (pores) occupied by nuclear pore complexes (NPCs), which mediate active and passive movement of molecules between the cytoplasm and nucleoplasm (Gruenbaum et al. 2005; Stewart et al. 2007). The NE and its lumen are continuous with the endoplasmic reticulum (ER) and share many
ER functions. However, the INM and ONM are also each structurally and functionally unique, because of specific enrichments for distinct integral membrane proteins (Schirmer and Gerace 2005; Schirmer and Foisner 2007). In mammals, the INM in particular appears to be populated by over 50 different membrane proteins, most of which are uncharacterized. Among characterized INM proteins, most can bind directly to A- or B-type lamins, or both.

A- and B-type lamins polymerize to form separate networks of nuclear intermediate filaments that concentrate near the INM in metazoans (Dechat et al. 2008). Many INM proteins are localized by binding directly or indirectly to lamin filaments. This network of filaments and

Editors: David Spector and Tom Misteli

Additional Perspectives on The Nucleus available at www.cshperspectives.org

Copyright (C) 2010 Cold Spring Harbor Laboratory Press; all rights reserved; doi: 10.1101/cshperspect.a000554

Cite this article as Cold Spring Harb Perspect Biol 2010;2:a000554 
lamin-binding proteins at the INM is known as the "peripheral lamina." B-type lamins are essential for cell viability and development, whereas A-type lamins arose later in evolution and are nonessential. Lamins are important structurally and as "scaffolds" for many other proteins and complexes in the nucleus.

Lamin filaments are important for the assembly, structure, shape, and mechanical stability of metazoan nuclei. There is also growing evidence that lamins regulate chromatin organization and gene expression, and influence signaling (Gruenbaum et al. 2005; Dechat et al. 2008). These functions involve a full spectrum of biochemical interactions between lamins, chromatin, and a variety of partners, including regulatory proteins responsive to external and intrinsic signals (Fig. 1). The pace of discovering new lamin-binding proteins has nearly overwhelmed our capacity to characterize them. Each new partner has the potential to provide fresh insight into the structure and regulation of the nucleoskeleton and its relationships with the genome. Further motivation for research in this area comes with the discovery that an increasing number of human diseases are linked to defects in lamins or lamin-binding proteins.

\section{THE CONCEPT OF LAMINA-ASSOCIATED POLYPEPTIDES}

The term lamina-associated-polypeptide (LAP) was coined to define a novel group of nuclear proteins that cofractionated with lamins and required high concentrations of monovalent salts and nonionic detergents to extract them from nuclei (Senior and Gerace 1988; Foisner

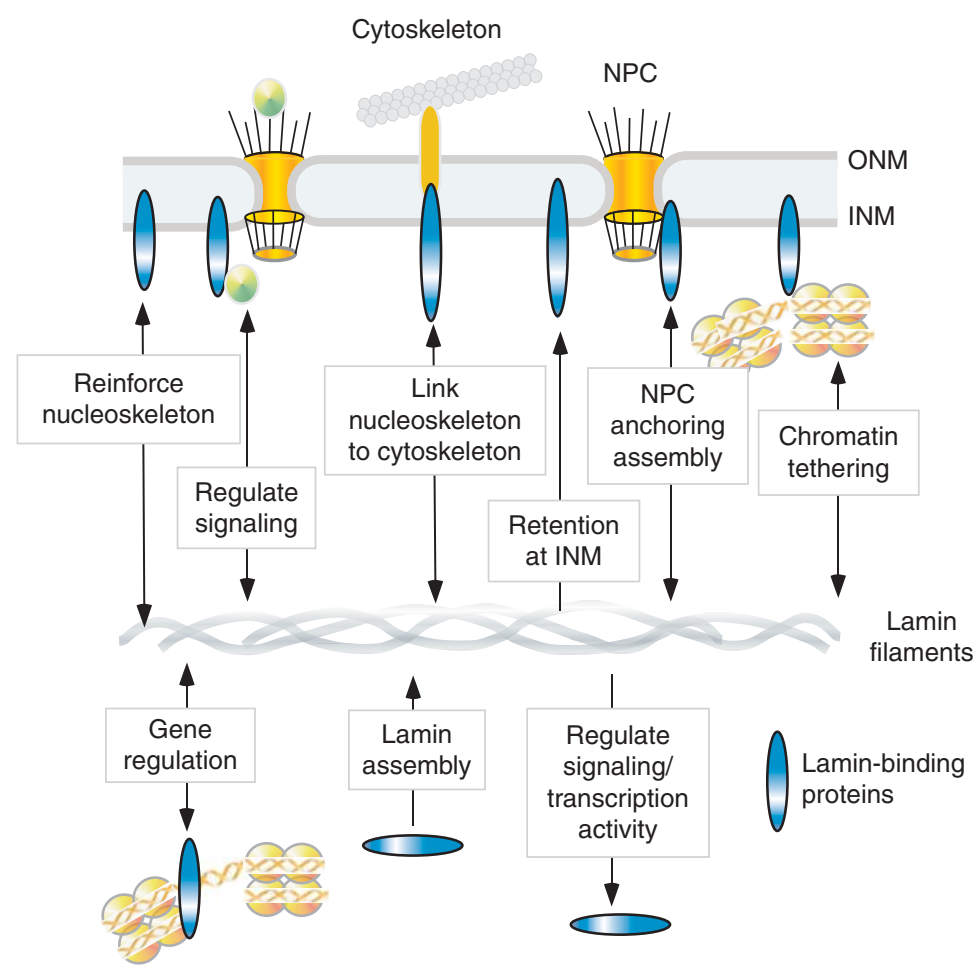

Figure 1. Overview of known roles for lamin-binding proteins. Many lamin-binding proteins located in the INM, on chromatin, and in the nucleoplasm are thought to have mechanical and structural roles, such as reinforcing the nucleoskeleton, interlinking the nucleoskeleton and cytoskeleton, anchoring NPCs, and tethering chromatin to the nuclear envelope. Others regulate signaling or transcription. Many lamin-binding proteins require lamins for their correct localization, whereas others regulate or facilitate lamin assembly. 
and Gerace 1993). The first characterized LAPs were all integral INM proteins: LAP1 (Martin et al. 1995) and LAP2 (Harris et al. 1994; Furukawa et al. 1995; Berger et al. 1996) each has one transmembrane domain and is expressed as multiple isoforms, whereas the so-called lamin $B$ receptor (LBR) has eight transmembrane domains (Worman et al. 1990). These proteins all bind lamins directly in vitro (Worman et al. 1988; Foisner and Gerace 1993; Furukawa et al. 1998). Since then, around 80 additional putative NE membrane proteins have been discovered (Schirmer et al. 2005; Schirmer and Foisner 2007). Most fit the original LAP criterion (resistance to biochemical extraction) and localize at the NE, but are untested for binding to lamins. The LAP concept expanded as lamins (Moir et al. 2000b; Naetar et al. 2008) and lamin-binding proteins including Narf (Barton and Worman 1999), LAP2 $\alpha$ (Naetar et al. 2008), and Lcol (Vlcek et al. 2004; Naetar et al. 2008) were discovered in the nuclear interior. Laminbinding proteins can have widely differing, and differentially regulated, affinities for lamins that might influence their biochemical extraction. Some proteins are known to bind lamins directly and relatively stably at the NE or in the nuclear interior. By contrast, other proteins bind lamins more transiently, probably as a means of regulating their activities; these partners include PCNA (Shumaker et al. 2008), c-Fos (Gonzalez et al. 2008), retinoblastoma (Rb) (Johnson et al. 2004; Pekovic et al. 2007), and Oct-1 (Malhas et al. 2009).

\section{LEM-DOMAIN PROTEINS AND BAF: TETHERING CHROMATIN TO THE NUCLEOSKELETON}

One prominent family of lamin-binding proteins involved in nuclear architecture and chromatin organization share the LEM (LAP2, Emerin, MAN) domain, an $\sim 45$-residue motif that folds as two $\alpha$-helices (Laguri et al. 2001). The LEM domain binds a conserved metazoan chromatin protein named Barrier to Autointegration Factor, BAF (Furukawa 1999; Cai et al. 2001; Lee et al. 2001; Shumaker et al. 2001; Shimi et al. 2004; Cai et al. 2007). BAF, a mobile lamin-binding protein, can "bridge" DNA and interacts with histones (Margalit et al. 2007). Most, but not all, LEM proteins are integral INM proteins with one or two transmembrane domains (Fig. 2). Mammals have four genes encoding characterized LEM proteins, LAP2 ( $\alpha, \beta$, and other isoforms), MAN1, emerin (Lin et al. 2000), and LEM2/NET25 (Schirmer et al. 2003; Brachner et al. 2005; Chen et al. 2006; Ulbert et al. 2006), and three uncharacterized genes encoding predicted nonmembrane proteins, LEM3, LEM4, and LEM5 (Lee and Wilson 2004), known respectively as ANKLE1, ANKLE2, and LEMD1. Three LEM proteins (emerin, LEM2, and LEM3) are conserved in Caenorhabditis elegans (Lee et al. 2000; Gruenbaum et al. 2002; Liu et al. 2003). Four are expressed in Drosophila: MAN1 (Wagner et al. 2006), otefin (Goldberg et al. 1998; Jiang et al. 2008), and Bocksbeutel $\alpha$ and $\beta$ (Wagner et al. 2004). The functions and interactions of LEM proteins, lamins, and BAF are strongly conserved between mammals, nematodes, and flies, suggesting they have fundamental roles in the nucleus.

Some LEM-domain proteins have additional domains that bind DNA, or other chromatin proteins. For example, LAP2 $\beta$ can bind HA95, a chromatin protein involved in DNA replication (Martins et al. 2003). All isoforms of LAP2 have a second "LEM-like" domain that binds DNA, rather than BAF (Cai et al. 2001; Laguri et al. 2001). Similarly, MAN1 and probably LEM2 binds DNA directly via a carboxyterminal "winged helix" domain (Caputo et al. 2006). Furthermore, all tested LEM proteins bind either A- or B-type lamins, or both, directly (Clements et al. 2000; Lee et al. 2001; Sakaki et al. 2001; Brachner et al. 2005; Mansharamani and Wilson 2005), and some require this interaction to localize at the NE (Sullivan et al. 1999; Vaughan et al. 2001; Brachner et al. 2005). Lamins, in turn, also directly bind DNA (Shoeman and Traub 1990; Luderus et al. 1992; Stierle et al. 2003) and histones (Taniura et al. 1995; Mattout et al. 2007). Thus, a complex network of interactions between lamins, LEM proteins, BAF, and, most likely, other INM proteins is involved in anchoring chromatin to the $\mathrm{NE}$ and lamins. 
K.L. Wilson and R. Foisner

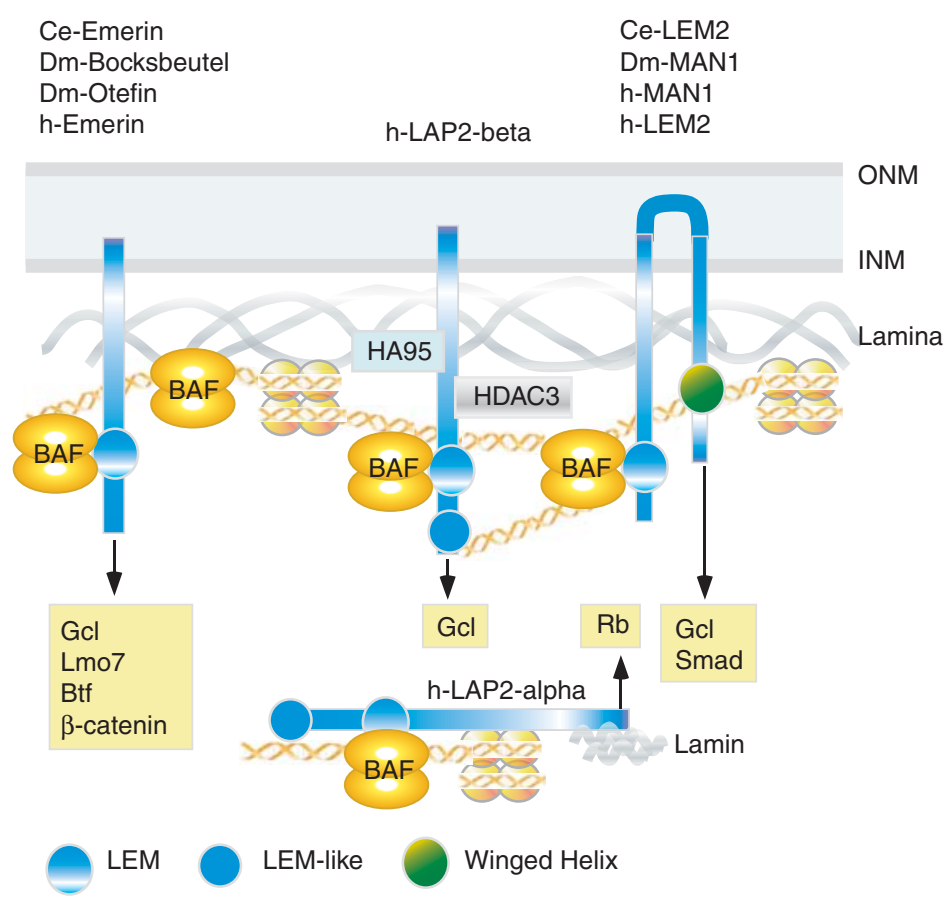

Figure 2. LEM-domain proteins organize chromatin and regulate signaling and transcription. Domain organizations of characterized LEM proteins; the LEM motif confers direct binding to barrier to autointegration factor (BAF). All LEM proteins can bind A- and/or B-type lamins. Some, including human (h-)emerin, C. elegans (Ce-) emerin, D. melanogaster (Dm-) bocksbeutel $\alpha$, and Dm-Otefin, have one transmembrane (TM) domain. LAP2 proteins, expressed only in vertebrates, also have a DNA-binding "LEM-like" domain. Others (e.g., hLem2, Ce-Lem2, hMAN1, and Dm-MAN1) have two TM domains and a carboxy-terminal Winged Helix domain that binds DNA. Some, including hLAP2 $\alpha$ (shown) and three uncharacterized LEM proteins (not shown), have no TM domain. LEM proteins have additional functional domains; e.g., LAP2 $\beta$ partners include replication protein HA95 and HDAC3; LAP2 $\beta$ recruits HDAC3 to the $\mathrm{NE}$ and contributes to epigenetic regulation. Emerin binds many transcription factors including GCL, Lmo7, Btf, and $\beta$-catenin. GCL also binds hLAP2 $\beta$ and hMAN1, suggesting functional overlap. MAN1 is unique in binding regulatory Smads, and inhibits BMP and TGF- $\beta$ signaling.

LEM proteins might appear to function redundantly in chromatin organization because there are so many of them, and functional inactivation of any single tested LEM gene does not grossly disrupt chromatin organization. Functional overlap is supported by C. elegans studies, which showed that double-knockdown of two LEM proteins (Ce-emerin and Ce-lem2) caused embryonic lethality at the 100-cell stage, when embryonic gene expression normally begins, with phenotypes that included aneuploidy, grossly defective chromatin organization and nuclear structure, and failure to assemble nuclei after mitosis (Liu et al. 2003). Nearly identical phenotypes are caused by down-regulating either Ce-lamin or BAF alone (Gruenbaum et al. 2005; Margalit et al. 2005a), strongly suggesting that BAF and LEM-domain proteins are key components of nuclear architecture.

Nevertheless, despite potential redundancies, eliminating just one LEM protein, for example emerin in mice, can affect nuclear structure: Emerin-null skeletal muscle nuclei are fragile (Ozawa et al. 2006), and show significantly increased autophagic degradation of structurally aberrant regions of the nucleus (Park et al. 2009a). Lamin mutations also cause obvious defects in nuclear shape and chromatin organization (Sabatelli et al. 2001; Scaffidi and Misteli 2006; Shumaker et al. 2006; Wang 
et al. 2006; Hakelien et al. 2008; Park et al. 2009 b), as well as enhanced autophagic degradation of nuclei (Park et al. 2009a). Further evidence for the physiological relevance of both lamins and LEM proteins in chromatin organization comes from recent genomewide studies to identify lamina-bound DNA. The analysis of methylated DNA in cultured Drosophila cells expressing lamin B1 fused to DNA methyltransferase (Dam), revealed $\sim 500$ genes in close contact with the lamina (Pickersgill et al. 2006). In human fibroblasts, this strategy revealed both lamin B1 and emerin in close contact with $>1300$ sharply defined domains in the genome, most of which were flanked either by binding sites for the insulator protein CTCF, or by E2F/DP-regulated promoters (Guelen et al. 2008). Interestingly, at least two INM LEM proteins, LAP2 $\beta$ and emerin, are implicated in the regulation of E2F/DP promoters (Nili et al. 2001; Holaska and Wilson 2006), and both CTCF and A-type lamins are required for the insulator function of a subtelomeric array of D4Z4 repeats, shortening of which cause Facio-Scapulo-Humeral Dystrophy (FSHD) (Ottaviani et al. 2009). Future application of genomewide "close contact" studies to other LEM proteins, and other types of lamin-binding proteins, may provide much-needed insight into their relationships with chromosomes. Interestingly, in proliferating cells, these "relationships" might be established actively while nuclei reassemble during mitotic anaphase and telophase. Nuclear assembly involves a complex series of interactions between chromatin, membranes, INM and ONM proteins, lamins, and other mitotically solubilized components, the mechanisms and regulation of which remain poorly understood (Margalit et al. 2005b; Anderson and Hetzer 2008; Guttinger et al. 2009). However, protein-protein interactions, for example between BAF, lamins, and LEM proteins, are required because nuclear assembly fails when one component is missing, as shown in C. elegans studies (Margalit et al. 2005b), and also fails in HeLa cells that express emerin and BAF mutants with impaired interactions (Haraguchi et al. 2001).

\section{LINC COMPLEXES LINK THE NUCLEAR INTERIOR TO THE CYTOPLASM}

Many independent studies in yeast, worms, flies, and mammals converged on a major discovery: Membrane proteins of the NE mechanically interlink the nucleoskeleton and cytoskeleton. These "LINC" complexes (Crisp et al. 2006) enable the regulated, cytoplasmic-motor-driven movement of the entire nucleus to new positions within the cell, and the movement of entire NE-tethered chromosomes to new positions along the NE (for reviews, see Tzur et al. 2006b; Wilhelmsen et al. 2006; Starr 2009). In addition, gene-regulatory responses to external force must now be assumed to potentially involve not only indirect signaling from the cell surface, but also direct signaling via mechanotransducing complexes at the NE.

Considered at the simplest level, LINC complexes consist of lamin-binding SUN-domain proteins in the INM that interact in the NE lumen with KASH-domain proteins (Fig. 3) anchored in the ONM (Hodzic et al. 2004; Padmakumar et al. 2005; Crisp et al. 2006; Haque et al. 2006); KASH proteins also bind directly or indirectly to cytoplasmic actin, microtubules, centrosomes, or intermediate filaments (Zhang et al. 2001; Zhen et al. 2002; Padmakumar et al. 2004; Wilhelmsen et al. 2005; McGee et al. 2006; Roux et al. 2009). It is important to note that at least two of the many $\mathrm{KASH}$-domain protein isoforms (nesprin-1 $\alpha$ and nesprin-2 $\beta$ ) are INM proteins that bind directly to lamins and emerin (Mislow et al. 2002a; Mislow et al. 2002b; Zhang et al. 2005).

SUN-domain proteins, conserved from yeast to humans, are defined by a 120 -residue motif located in the lumenal space of the NE; the name SUN was based on S. pombe Sad1 and D. melanogaster UNC-84 (Malone et al. 1999). C. elegans and D. melanogaster each have two SUN genes: UNC84 and germ-cell-specific matefin/SUN1 in C. elegans, and Klaroid and CG6589 in Drosophila. Mammals have four: SUN1 and SUN2, and testis-specific genes SUN3 and Spag4 (reviewed in Starr 2009). Human SUN1 (hSUN1) and hSUN2 each have a coiled-coil domain near the SUN domain that 


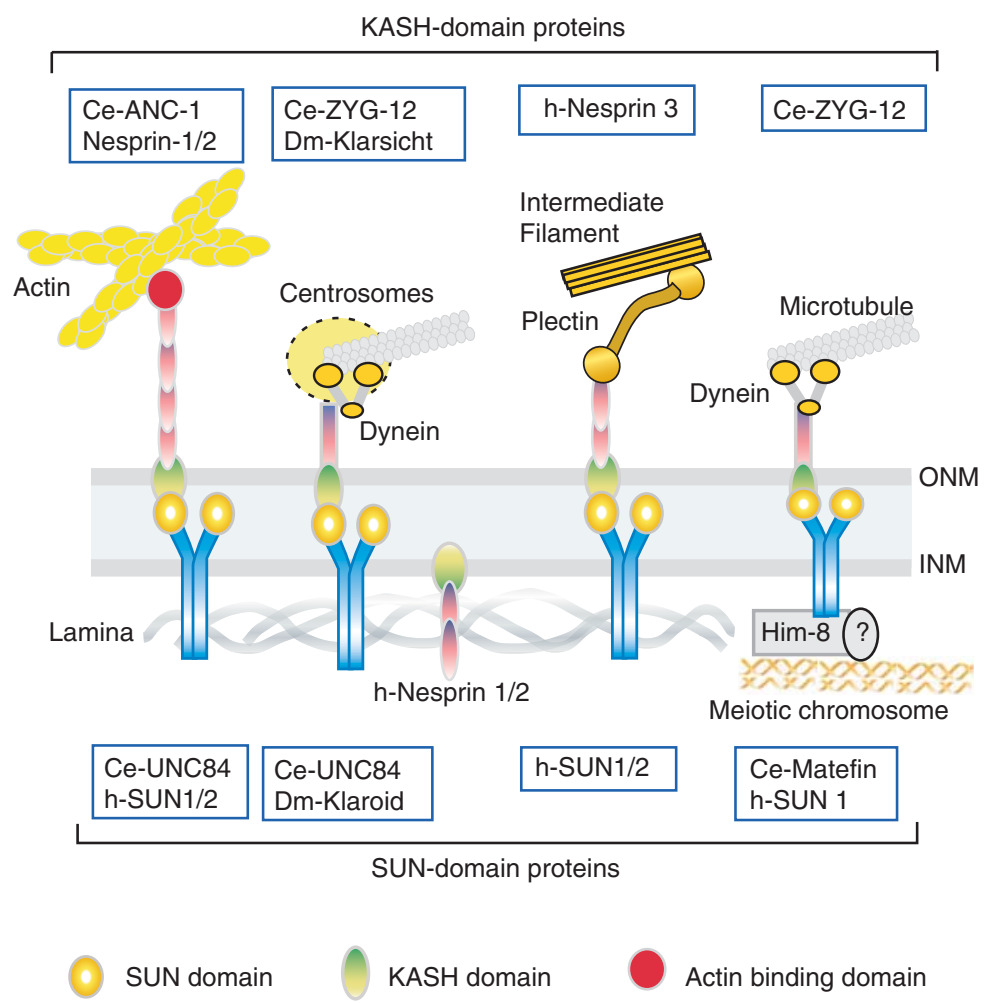

Figure 3. SUN- and KASH-domain proteins interact in the NE lumen to form LINC (Links Nucleoskeleton and Cytoskeleton) complexes. SUN-domain proteins span the INM and dimerize; each nucleoplasmic domain binds lamins and each SUN-domain in the NE lumen binds the KASH domain of an ONM-embedded KASH protein, which binds actin, centrosomes/microtubules, or plectin/intermediate filaments in the cytoplasm. Only one KASH domain partner of a SUN dimer is depicted. SUN proteins also bind, potentially via Him-8, the pairing centers of meiotic chromosomes. Many additional nesprin isoforms reside elsewhere, including the INM; e.g., human nesprins- $1 \alpha$ and $-2 \beta$ in the INM bind lamins and emerin (not shown).

mediates dimerization and is also involved in binding the KASH domain; their exposed nucleoplasmic amino-terminal domain binds lamins (reviewed by Tzur et al. 2006b; Starr 2009).

KASH- (Klarsicht, ANC-1, Syne homology) domain nomenclature is confusing because these proteins were identified in diverse species before their conservation was recognized. Mammalian KASH proteins are now known as "nesprins." The KASH domain comprises a single carboxy-terminal transmembrane domain followed by a 35-residue lumenal domain. ONM-localized KASH proteins require the interaction with SUN-domain proteins for retention at the ONM. C. elegans encodes three known KASH-domain proteins (ANC-1, UNC-83, and ZYG-12) (Starr and Han 2002; Malone et al. 2003; McGee et al. 2006) and D. melanogaster encodes the two proteins Klarsicht and MSP 300 (Patterson et al. 2004; Xie and Fischer 2008). Nesprin isoform complexity is much higher in mammals, which have four known genes: Nesprin-1 (SYNE1), nesprin-2 (SYNE2), nesprin-3, and nesprin-4. The Nesprin-1 and -2 genes are alternatively transcribed and alternatively spliced to produce more than 12 protein isoforms each, from small to enormous ( $>1$ $\mathrm{MDa})$. Some isoforms lack the KASH domain and are not membrane-localized, whereas others localize at the INM or even the Golgi complex (Starr and Fischer 2005; Wilhelmsen et al. 
2006). All nesprins have multiple "spectrin repeat" domains that confer an extended configuration, but can also mediate specific proteinprotein interactions. For example, specific spectrin repeat domains in the small, INM-localized isoform nesprin- $1 \alpha$ mediate direct binding to lamins, emerin, and other nesprin- $1 \alpha$ molecules (Mislow et al. 2002a). The largest isoforms of nesprin-1 and -2 bind actin (Zhen et al. 2002; Padmakumar et al. 2004). Nesprin-3 binds plectin, a cytoskeletal protein that binds cytoplasmic intermediate filaments (Wilhelmsen et al. 2005), whereas nesprin-4 binds kinesin 1, a plus-enddirected microtubule-dependent motor, and may be involved in dislocalizing the centrosome and Golgi membranes away from the nucleus in epithelial cells (Roux et al. 2009).

LINC complexes formed by SUN- and KASHdomain proteins are known to determine the spacing between the INM and ONM (Crisp et al. 2006), position NPCs (Liu et al. 2007), and control nuclear size and NE architecture (Luke et al. 2008). Different combinations of SUN- and KASH-domain proteins mediate different functions (Fig. 3), including forcetransfer across the NE, and the stiffness of the cytoskeleton (Stewart-Hutchinson et al. 2008). In C. elegans, the SUN protein UNC84 anchors nuclei to cytoplasmic actin filaments via the KASHdomain protein ANC-1 (Malone et al. 1999; Starr and Han 2002), mediates movement of nuclei via a different KASH partner (UNC-83) (Starr et al. 2001), and attaches centrosomes to the NE via a third KASH partner (ZYG-12) and the dynein subunit DLI-1 (Malone et al. 2003) (Fig. 3). The other C. elegans SUN-domain protein, matefin/SUN1, is also required to recruit the proapoptotic protein CED-4 to the NE (Tzur et al. 2006a), implying additional roles for LINC complexes in death signaling. In Drosophila, LINC complexes mediate centrosome attachment to the NE, and nuclear migration in developing photoreceptor cells (Patterson et al. 2004; Kracklauer et al. 2007). In mice, deletions in the nesprin-1 or nesprin-2 genes, or overexpression of the KASH-domain, which destroys endogenous LINC complexes, disrupts nuclear organization, results in failure of nuclei to cluster at neuromuscular junctions (Grady et al. 2005;
Zhang et al. 2007), and can cause muscular dystrophy (Puckelwartz et al. 2009).

Amazingly, LINC complexes can also transmit mechanical force from the cytoskeleton through the NE to move chromosomes, for example during meiotic prophase, when telomeres attach to the NE and cluster to form bouquet-like structures that facilitate chromosome pairing (Chikashige et al. 2007). In a C. elegans matefin/ SUN1 mutant strain, chromosome reorganization is disrupted in early meiosis, and ZYG-12 "patches" do not form on the NE (Penkner et al. 2007). This suggests meiotic chromosome clustering and homolog recognition requires both matefin/SUN1 and ZYG-12 (a KASH-domain protein), potentially via HIM-8-mediated attachment of pairing centers to matefin/SUN1 (Penkner et al. 2007). Similarly, mammalian SUN1 and SUN2 (Ding et al. 2007; Schmitt et al. 2007) are telomere-associated between the leptotene and diplotene stages of meiosis, and SUN1-knockout mice have both impaired NE-telomere association and impaired homolog pairing (Ding et al. 2007). The meiotic functions of mammalian SUN proteins do not require A-type lamins (Schmitt et al. 2007). Potential roles for B-type lamin(s) remain to be tested in mammals, and seem likely because in C. elegans the nuclear migration and nuclear anchoring functions of LINC complexes require the one (B-type) lamin expressed in this organism (Lee et al. 2002). However, similar SUN- and KASH-dependent pathways exist in S. pombe and S. cerevisiae, which do not have lamins (Starr 2009).

It is unknown how the functions and interactions of SUN and KASH proteins are regulated (Starr 2009). One interesting possibility is that LINC complexes might be regulated by proteins located in the NE lumen. This possibility is suggested by Torsin A, a so-called "AAA + ATPase" enzyme located in the NE/ER lumen that is required to localize nesprin (Nery et al. 2008).

\section{REGULATION OF SIGNALING AND DIFFERENTIATION BY LAMIN-BINDING PROTEINS}

The plasma membrane contains many structural complexes (e.g., focal adhesions and dystroglycan 
complex) that can be dynamically regulated and generate signals to which cells respond in a tissue-specific manner, in many cases at the level of gene regulation. There is increasing evidence that this paradigm might also apply to laminassociated protein complexes at the NE, and in the nucleoplasm. The concept of "lamin-linked dynamic signaling" is supported by studies on several LEM-domain proteins. For example, LAP2 $\beta$, the largest INM-localized LAP2 isoform, binds lamin B specifically, and also directly interacts with transcription regulators (e.g., GCL) and epigenetic modifiers including HDAC3, and contributes to transcriptional repression (Nili et al. 2001; Somech et al. 2005). Interestingly, another INM-localized LEM protein, MAN1, directly binds and inhibits $\mathrm{R}-\mathrm{Smads}$ and functions as a major regulator of BMP- and TGF- $\beta$-signaling in early vertebrate development (Osada et al. 2003; Raju et al. 2003; Lin et al. 2005; Mansharamani and Wilson 2005; Pan et al. 2005; Cohen et al. 2007). Roles for lamin-binding proteins in TGF- $\beta$-signaling are also reported in Drosophila: The INM-localized LEM protein Otefin binds directly to Medea (Smad-4) and they physically tether their repressed target locus, bam ("bag of marbles"), at the NE (Jiang et al. 2008).

The INM protein emerin also supports the paradigm of complex regulation of proteinprotein interactions and signaling at the NE. Emerin directly binds more than ten known partners, suggesting a degree of biochemical complexity at the NE that rivals many cell surface structures. Among these partners are structural proteins (nesprin- $1 \alpha$, nesprin- $2 \beta$, actin, nuclear myosin $1 \mathrm{c}$, lamins, and tubulin), other INM proteins (MAN1 and LUMA), proteins involved in signaling, transcription, mRNA splicing ( $\beta$-catenin, GCL, Lmo7, Btf, and YT521-B), and of course, BAF (Lee et al. 2001; Mislow et al. 2002a; Holaska et al. 2003; Haraguchi et al. 2004; Holaska et al. 2004; Mansharamani and Wilson 2005; Holaska et al. 2006; Markiewicz et al. 2006; Wheeler et al. 2007; Bengtsson and Otto 2008) (for reviews, see Bengtsson and Wilson 2004; Wagner and Krohne 2007). The biochemical purification of emerin-associated protein complexes from HeLa cell nuclei suggests emerin can form at least six distinct multiprotein complexes (Holaska and Wilson 2007). Some putative complexes included primarily architectural components (e.g., lamins, actin, nuclear myosin 1c, and nuclear $\alpha \mathrm{II}-$ spectrin), whereas others included chromatin and gene regulators (e.g., histones, $\mathrm{Lmo}$, $\mathrm{Rb}$, and components of the Nuclear Co-Repressor [ $\mathrm{NCoR}$ ] complex). Emerin may also be involved in sensing and responding to mechanical tension at the NE (Lammerding et al. 2005). The interaction of Lmo7 (Holaska et al. 2006) and $\beta$-catenin (Markiewicz et al. 2006) with emerin regulates their nuclear export and represses their activity. These regulatory functions may be important for muscle and adipocyte differentiation, respectively (Holaska et al. 2006; Tilgner et al. 2009). It is still unclear how emerin regulates the nuclear export of these factors. Emerin was also reported to localize in the ONM and mediate centrosome-NE attachment (Salpingidou et al. 2007).

How emerin "knows" when to assemble or disassemble particular complexes, and how its localization in the INM versus ONM is regulated, are important open questions. Growing evidence that emerin is phosphorylated suggests mechanisms by which different kinases and signaling pathways might directly control its binding to specific partners, including $\mathrm{BAF}$ (Hirano et al. 2005; Roberts et al. 2006; Schlosser et al. 2006; Luo et al. 2009).

\section{REGULATION OF SIGNALING AND \\ PROLIFERATION CONTROL BY LAMIN-BINDING PROTEINS IN THE NUCLEAR INTERIOR}

The largest LAP2 isoform, LAP2 $\alpha$, lacks a transmembrane domain, localizes to the nuclear interior, and specifically binds A-type lamins (Dechat et al. 2000; Vlcek et al. 2002; Dechat et al. 2004). In proliferating cells, LAP2 $\alpha$ is essential and sufficient to target and retain a subset of lamins within the nuclear interior (Naetar et al. 2007; Naetar et al. 2008). Nucleoplasmic lamins are stable, but more mobile than peripheral lamins, suggesting interior lamins assemble 
differently or bind to chromatin (Moir et al. 2000b). LAP $2 \alpha$ and lamin A also bind directly to tumor suppressor Rb (Ozaki et al. 1994; Markiewicz et al. 2002; Pekovic et al. 2007), and LAP $2 \alpha$ is involved in $\mathrm{Rb}$-mediated repression of $\mathrm{E} 2 \mathrm{~F} / \mathrm{Rb}$ target genes (Dorner et al. 2006) and $\mathrm{Rb}$-dependent proliferation control in tissue progenitor stem cells (Naetar et al. 2008). The physiological relevance of intranuclear LAP $2 \alpha$-lamin complexes in $\mathrm{Rb}$ regulation is supported by studies showing destabilization and proteolytic degradation (Johnson et al. 2004; Nitta et al. 2006; Nitta et al. 2007) and impaired phosphorylation-dependent repressor activity control (Van Berlo et al. 2005) of Rb in cells lacking A-type lamins.

\section{"FAMILIAR" REGULATORY PROTEINS AND ENZYMES DISCOVERED TO BIND LAMINS}

In addition to $\mathrm{Rb}$, other known transcription factors and regulators have been discovered to bind A- and/or B-type lamins directly. This binding, whether transient or stable in vivo, suggests these proteins-and pathways they represent-either require or are influenced by lamins. These lamin-binding proteins include cyclin D3 (Mariappan et al. 2007), transcription factors cFos, Oct-1, SREBP1, MOK2, and tumor suppressor ING1 (Han et al. 2008), an enzyme named 12(S)-lipoxygenase (12[S] LOX) (Tang et al. 2000), and at least two kinases: protein kinase $\mathrm{C} \alpha(\mathrm{PKC} \alpha)$ and JIL-1 kinase (Bao et al. 2005) (reviewed in Zastrow et al. 2004; Vlcek and Foisner 2007). Binding to lamin B1 sequesters transcription factor Oct-1 at the NE, away from promoters; in lamin B1-deficient cells, Oct-1-dependent genes that respond to oxidative stress and reactive oxygen species are misregulated (Malhas et al. 2009). Similarly, c-Fos, an early response transcription factor, is sequestered at the NE by A-type lamins (Ivorra et al. 2006) and during mitogen activated protein (MAP) kinase signaling, activated ERK1/2 interacts with lamin A and c-Fos at the NE to rapidly release c-Fos and facilitate cell proliferation (Gonzalez et al. 2008). Deregulation of this pathway in emerin and lamin A-deficient cells might up-regulate ERK-mediated signaling, a known phenotype of certain lamin- or emerindeficient cells (Muchir et al. 2007; Muchir et al. 2009). Lamin A is also reported to affect Notch signaling, required to differentiate mesenchymal stem cells, by tethering SKIP, a coactivator of Notch-dependent target genes (Scaffidi and Misteli 2008). A better understanding of these interactions is sorely needed because it might begin to illuminate how and why nuclear architecture defects, for example in accelerated aging or other diseases linked to mutations in lamins and lamin-binding proteins, might disrupt signaling and gene regulation pathways.

The nuclear import receptor, importin $\alpha$, is also a lamin-binding protein (Adam et al. 2008). Importin $\alpha$ inhibits lamin assembly in vitro, suggesting it prevents newly synthesized lamins from assembling in the cytoplasm; this interaction is disrupted by Ran-GTP, found at high levels only within nuclei, releasing the assembly block once lamins are in the nucleus.

PCNA, the Sliding Clamp "Ring" for DNA Replication, Binds Lamins

Lamins are also involved in DNA replication. Replication is a structural challenge, because replication complexes must traverse each huge chromosome, including regions tethered as heterochromatin to the NE. DNA replication complexes are anchored to nucleoskeletal structures (Hozak et al. 1993). During replication, the NE-anchored heterochromatin becomes disconnected, moves to replication complexes, and is then retethered at the $\mathrm{NE}$ ( $\mathrm{Li}$ et al. 1998). DNA replication arrests at the elongation phase in nuclei subjected to lamina network disruption by "dominant-negative" lamin fragments (Spann et al. 1997; Moir et al. 2000a). In a breakthrough for this understudied area, PCNA (proliferating cell nuclear antigen), which forms a sliding clamp "ring" ahead of the replication fork, was found to bind lamins directly (Shumaker et al. 2008). Further study of PCNA, the first but perhaps not the only lamin-binding component of DNA replication machinery, might shed light on how and why this fundamental process came to depend on the nucleoskeleton and lamins in metazoans. 


\section{LAMIN-BINDING PROTEINS AND HUMAN DISEASE}

The diversity and physiological relevance of lamin-binding proteins is reflected in the growing number of human diseases linked to genes encoding lamins or lamin-binding proteins (Broers et al. 2006; Capell and Collins 2006; Worman and Bonne 2007). These diseases are known collectively as "laminopathies" or "envelopathies." More than 12 overlapping or distinct syndromes including autosomal dominant Emery-Dreifuss muscular dystrophy (ADEDMD) are caused by mutations in the gene encoding A-type lamins (LMNA). In several cases, the same or clinically indistinguishable diseases can also be caused by mutations in one or more lamin-binding proteins. For example, EDMD is also caused by X-linked recessive loss of emerin (Bione et al. 1994), or dominant missense mutations in SYNE1 or SYNE2, encoding nesprin-1 and nesprin-2, respectively (Zhang et al. 2007; Puckelwartz et al. 2009). These similar pathologies suggest the disruption of a functional complex(es) that requires products of all four genes (Gotzmann and Foisner 2006). On the other hand, mutations in emerin can also cause other syndromes including Limb-Girdle muscular dystrophy, cardiomyopathy with conduction defects, or familial atrial fibrillation (Ben Yaou et al. 2007; Ura et al. 2007; Karst et al. 2008). "Classical" EDMD is characterized by progressive muscle wasting, contractures of tendons, and cardiomyopathy with ventricular conduction system defects (Bione et al. 1994; Manilal et al. 1996). Most X-linked EDMD patients are functionally null for emerin because of instability of the mutated protein or, more rarely, failed INM retention of mutant emerin proteins. In many AD-EDMD patients with LMNA mutations, emerin drifts into the ER and is functionally lost from the NE (Broers et al. 2006; Worman and Bonne 2007); however, with LMNA mutations, one must assume many additional INM or ONM proteins similarly mislocalize, if their retention at the NE requires A-type lamins. Gene-expression profiling of muscle biopsies from EDMD patients (Bakay et al. 2006) and emerin-down-regulated mouse cells (Melcon et al. 2006) suggested shared defects in the expression of genes regulated by $R b 1$ and $M y o D$, which are required for muscle stem cell regulation and muscle differentiation (Gotzmann and Foisner 2006). A mutation in LAP $2 \alpha$ that disrupts binding to lamin $\mathrm{A}$ is known to cause dilated cardiomyopathy (Taylor et al. 2005). Whether this mutation might also impair $\mathrm{Rb}$ activity, or reflect a novel role of LAP $2 \alpha$, is unknown. Additional disease mechanisms are suggested by the impaired organization and function of the neuromuscular junction in lamin-null mice and AD-EDMD patients (Mejat et al. 2009), and evidence that emerin is regulated by Her2 signaling (Tifft et al. 2009).

\section{"Signaling" Laminopathies Linked to MAN1 and LBR}

Heterozygous loss-of-function mutations in MAN1 (LEMD3) cause osteopoikilosis, Buschke-Ollendorff syndrome, and melorheostosis, characterized by increased bone density (Hellemans et al. 2004). This pathology may result from impaired MAN1 regulation of TGF- $\beta$ (Smad) signaling (discussed above), which is important for bone development.

LBR, the INM-localized sterol reductase that also binds lamin $\mathrm{B}$, is required for nuclei to change shape and reorganize chromatin in differentiating neutrophils (Hoffmann et al. 2002). LBR is proposed to associate with heterochromatic under-acetylated chromatin (Polioudaki et al. 2001; Makatsori et al. 2004) through binding to heterochromatin protein 1 (HP1) (Ye and Worman 1996). Heterozygous LBR mutations cause Pelger-Huet anomaly, a benign autosomal dominant syndrome characterized by abnormal nuclear shape and chromatin organization in blood granulocytes (Hoffmann et al. 2002). Greater loss of LBR protein correlates with more severe phenotypes, including developmental delay, epilepsy, and skeletal abnormalities (Hoffmann et al. 2007). Mutations that significantly reduce the sterol reductase activity of LBR are linked to autosomal recessive Greenberg's skeletal dysplasia, characterized by lethal skeletal and visceral anomalies (Waterham et al. 2003). 
Central Nervous System (CNS) Laminopathies

Brain pathologies with genetic links to lamins or lamin-binding proteins were noticeably missing, until recently. Surprisingly, the duplication of LMNB1, encoding lamin B1, causes autosomal dominant leukodystrophy, a slowly progressive disorder characterized by widespread demyelination of the CNS (Padiath et al. 2006; Brussino et al. 2009). Proper regulation of lamin B1 expression is crucial for oligodendrocyte development and myelination (Lin and Fu 2009). The lamin B1-binding proteins and pathways that underlie these functions in the brain are open questions.

Primary dystonia is a CNS-based autosomal-dominant movement disorder caused by mutations in the AAA+ATPase torsin A. This brain pathology was traced to the aberrantly tight binding of the mutated torsin A protein to the lumenal domain of LAP1 (Naismith et al. 2004; Goodchild and Dauer 2005), an INM protein that binds A- and B-type lamins. Wild-type torsin A is recruited to the NE by LAP1 when ATP is bound, whereas torsin A distributes throughout the ER lumen in the absence of ATP; the immobilization of mutant torsin A in the NE lumen correlates with cytoskeletal protein accumulation near the NE and disrupted cytoskeletal dynamics, neurite extension, and cell adhesion (Hewett et al. 2006).

In addition to causing EDMD, other mutations in nesprin-1 (SYNE1) can cause autosomal-recessive cerebellar ataxia (Gros-Louis et al. 2007), characterized by impaired walking. Although this pathology might reflect impaired function of a brain-specific postsynaptic nesprin-1 isoform, parallel disruption of nuclear isoforms cannot be ruled out.

\section{CONCLUDING REMARKS}

Lamin-binding proteins are an emerging class of proteins that may explain how chromosomes are organized, how nuclei are assembled after mitosis or moved to new positions in the cell, and how transcription, replication, signaling, and many other activities are supported by lamin filaments and the nucleoskeleton. Further exploration of this understudied area of cell biology may lead to improved and potentially therapeutic understanding of many human diseases.

\section{ACKNOWLEDGMENTS}

We gratefully acknowledge grant support from the Austrian Science Research Fund (FWF P17871) and the EURO-Laminopathies research project of the European Commission (Contract LSHM-CT-2005-018690) to R.F. and National Institutes of Health Directors Bridge Award (2R56GM08646-13A1) to K.L.W.

\section{REFERENCES}

Adam SA, Sengupta K, Goldman RD. 2008. Regulation of nuclear lamin polymerization by importin $\alpha$. J Biol Chem 283: $8462-8468$.

Anderson DJ, Hetzer MW. 2008. Shaping the endoplasmic reticulum into the nuclear envelope. J Cell Sci 121: 137-142.

Bakay M, Wang Z, Melcon G, Schiltz L, Xuan J, Zhao P, Sartorelli V, Seo J, Pegoraro E, Angelini C, et al. 2006. Nuclear envelope dystrophies show a transcriptional fingerprint suggesting disruption of Rb-MyoD pathways in muscle regeneration. Brain 129: 996-1013.

Bao X, Zhang W, Krencik R, Deng H, Wang Y, Girton J, Johansen J, Johansen KM. 2005. The JIL-1 kinase interacts with lamin Dm0 and regulates nuclear lamina morphology of Drosophila nurse cells. J Cell Sci 118: 5079-5087.

Barton RM, Worman HJ. 1999. Prenylated prelamin A interacts with Narf, a novel nuclear protein. J Biol Chem 274: 30008-30018.

Ben Yaou R, Toutain A, Arimura T, Demay L, Massart C, Peccate C, Muchir A, Llense S, Deburgrave N, Leturcq F, et al. 2007. Multitissular involvement in a family with LMNA and EMD mutations: Role of digenic mechanism? Neurology 68: 1883-1894.

Bengtsson L, Otto H. 2008. LUMA interacts with emerin and influences its distribution at the inner nuclear membrane. J Cell Sci 121: 536-548.

Bengtsson L, Wilson KL. 2004. Multiple and surprising new functions for emerin, a nuclear membrane protein. Curr Opin Cell Biol 16: 73-79.

Berger R, Theodor L, Shoham J, Gokkel E, Brok-Simoni F Avraham KB, Copeland NG, Jenkins NA, Rechavi G, Simon AJ. 1996. The characterization and localization of the mouse thymopoietin/lamina- associated polypeptide 2 gene and its alternatively spliced products. Genome Res 6: 361-370.

Bione S, Maestrini E, Rivella S, Mancini M, Regis S, Romeo G, Toniolo D. 1994. Identification of a novel X-linked gene responsible for Emery-Dreifuss muscular dystrophy. Nature Genet 8: 323-327. 


\section{K.L. Wilson and R. Foisner}

Brachner A, Reipert S, Foisner R, Gotzmann J. 2005. LEM2 is a novel MAN1-related inner nuclear membrane protein associated with A-type lamins. J Cell Sci 118: 5797-5810.

Broers JL, Ramaekers FC, Bonne G, Yaou RB, Hutchison CJ. 2006. Nuclear lamins: Laminopathies and their role in premature ageing. Physiol Rev 86: 967-1008.

Brussino A, Vaula G, Cagnoli C, Mauro A, Pradotto L, Daniele D, Di Gregorio E, Barberis M, Arduino C, Squadrone S, et al. 2009. A novel family with Lamin B1 duplication associated with adult-onset leucoencephalopathy. J Neurol Neurosurg Psychiatry 80: 237-240.

Cai M, Huang Y, Ghirlando R, Wilson KL, Craigie R, Clore GM. 2001. Solution structure of the constant region of nuclear envelope protein LAP2 reveals two LEM-domain structures: One binds BAF and the other binds DNA. EMBO J 20: 4399-4407.

Cai M, Huang Y, Suh JY, Louis JM, Ghirlando R, Craigie R, Clore GM. 2007. Solution NMR structure of the barrierto-autointegration factor-Emerin complex. J Biol Chem 282: 14525-14535.

Capell BC, Collins FS. 2006. Human laminopathies: Nuclei gone genetically awry. Nat Rev Genet 7: 940-952.

Caputo S, Couprie J, Duband-Goulet I, Konde E, Lin F, Braud S, Gondry M, Gilquin B, Worman HJ, Zinn-Justin S. 2006. The carboxyl-terminal nucleoplasmic region of MAN1 exhibits a DNA binding winged helix domain. $J$ Biol Chem 281: 18208-18215.

Chen IH, Huber M, Guan T, Bubeck A, Gerace L. 2006 Nuclear envelope transmembrane proteins (NETs) that are up-regulated during myogenesis. BMC Cell Biol 7: 38 .

Chikashige Y, Haraguchi T, Hiraoka Y. 2007. Another way to move chromosomes. Chromosoma 116: 497-505.

Clements L, Manilal S, Love DR, Morris GE. 2000. Direct interaction between emerin and lamin A. Biochem Biophys Res Commun 267: 709-714.

Cohen TV, Kosti O, Stewart CL. 2007. The nuclear envelope protein MAN1 regulates TGF $\beta$ signaling and vasculogenesis in the embryonic yolk sac. Development 134: 1385-1395.

Crisp M, Liu Q, Roux K, Rattner JB, Shanahan C, Burke B Stahl PD, Hodzic D. 2006. Coupling of the nucleus and cytoplasm: Role of the LINC complex. J Cell Biol 172: $41-53$.

Dechat T, Gajewski A, Korbei B, Gerlich D, Daigle N, Haraguchi T, Furukawa K, Ellenberg J, Foisner R. 2004. LAP $2 \alpha$ and BAF transiently localize to telomeres and specific regions on chromatin during nuclear assembly. J Cell Sci 117: 6117-6128.

Dechat T, Korbei B, Vaughan OA, Vlcek S, Hutchison CJ, Foisner R. 2000. Lamina-associated polypeptide $2 \alpha$ binds intranuclear A-type lamins. J Cell Sci 113: 3473-3484.

Dechat T, Pfleghaar K, Sengupta K, Shimi T, Shumaker DK, Solimando L, Goldman RD. 2008. Nuclear lamins: Major factors in the structural organization and function of the nucleus and chromatin. Genes Dev 22: 832-853.

Ding X, Xu R, Yu J, Xu T, Zhuang Y, Han M. 2007. SUN1 is required for telomere attachment to nuclear envelope and gametogenesis in mice. Dev Cell 12: 863-872.
Dorner D, Vlcek S, Foeger N, Gajewski A, Makolm C, Gotzmann J, Hutchison CJ, Foisner R. 2006. Lamina-associated polypeptide $2 \alpha$ regulates cell cycle progression and differentiation via the retinoblastoma-E2F pathway. $J$ Cell Biol 173: 83-93.

Foisner R, Gerace L. 1993. Integral membrane proteins of the nuclear envelope interact with lamins and chromosomes, and binding is modulated by mitotic phosphorylation. Cell 73: 1267-1279.

Furukawa K. 1999. LAP2 binding protein 1 (L2BP1/BAF) is a candidate mediator of LAP2- chromatin interaction. J Cell Sci 112: 2485-2492.

Furukawa K, Fritze CE, Gerace L. 1998. The major nuclear envelope targeting domain of LAP2 coincides with its lamin binding region but is distinct from its chromatin interaction domain. J Biol Chem 273: 4213-4219.

Furukawa K, Pante N, Aebi U, Gerace L. 1995. Cloning of a cDNA for lamina-associated polypeptide 2 (LAP2) and identification of regions that specify targeting to the nuclear envelope. $E M B O J$ 14: 1626-1636.

Goldberg M, Lu H, Stuurman N, Ashery-Padan R, Weiss AM, Yu J, Bhattacharyya D, Fisher PA, Gruenbaum Y, Wolfner MF. 1998. Interactions among Drosophila nuclear envelope proteins lamin, otefin, and YA. Mol Cell Biol 18: 4315-4323.

Gonzalez JM, Navarro-Puche A, Casar B, Crespo P, Andres V. 2008. Fast regulation of AP-1 activity through interaction of lamin A/C, ERK1/2, and c-Fos at the nuclear envelope. J Cell Biol 183: 653-666.

Goodchild RE, Dauer WT. 2005. The AAA + protein torsinA interacts with a conserved domain present in LAP1 and a novel ER protein. J Cell Biol 168: 855-862.

Gotzmann J, Foisner R. 2006. A-type lamin complexes and regenerative potential: A step towards understanding laminopathic diseases? Histochem Cell Biol 125: 33-41.

Grady RM, Starr DA, Ackerman GL, Sanes JR, Han M. 2005. Syne proteins anchor muscle nuclei at the neuromuscular junction. Proc Natl Acad Sci 102: 4359-4364.

Gros-Louis F, Dupre N, Dion P, Fox MA, Laurent S, Verreault S, Sanes JR, Bouchard JP, Rouleau GA. 2007. Mutations in SYNE1 lead to a newly discovered form of autosomal recessive cerebellar ataxia. Nat Genet 39: $80-85$.

Gruenbaum Y, Lee KK, Liu J, Cohen M, Wilson KL. 2002. The expression, lamin-dependent localization and RNAi depletion phenotype for emerin in C. elegans. $J$ Cell Sci 115: 923-929.

Gruenbaum Y, Margalit A, Goldman RD, Shumaker DK, Wilson KL. 2005. The nuclear lamina comes of age. Nat Rev Mol Cell Biol 6: 21-31.

Guelen L, Pagie L, Brasset E, Meuleman W, Faza MB, Talhout W, Eussen BH, de Klein A, Wessels L, de Laat W, et al. 2008. Domain organization of human chromosomes revealed by mapping of nuclear lamina interactions. Nature 453: $948-951$.

Guttinger S, Laurell E, Kutay U. 2009. Orchestrating nuclear envelope disassembly and reassembly during mitosis. Nat Rev Mol Cell Biol 10: 178-191.

Hakelien AM, Delbarre E, Gaustad KG, Buendia B, Collas P. 2008. Expression of the myodystrophic R453W mutation 
of lamin A in C2C12 myoblasts causes promoter-specific and global epigenetic defects. Exp Cell Res 314: 18691880.

Han X, Feng X, Rattner JB, Smith H, Bose P, Suzuki K, Soliman MA, Scott MS, Burke BE, Riabowol K. 2008. Tethering by lamin A stabilizes and targets the ING1 tumour suppressor. Nat Cell Biol 10: 1333-1340.

Haque F, Lloyd DJ, Smallwood DT, Dent CL, Shanahan CM, Fry AM, Trembath RC, Shackleton S. 2006. SUN1 interacts with nuclear lamin A and cytoplasmic nesprins to provide a physical connection between the nuclear lamina and the cytoskeleton. Mol Cell Biol 26: 3738-3751.

Haraguchi T, Holaska JM, Yamane M, Koujin T, Hashiguchi N, Mori C, Wilson KL, Hiraoka Y. 2004. Emerin binding to Btf, a death-promoting transcriptional repressor, is disrupted by a missense mutation that causes EmeryDreifuss muscular dystrophy. Eur J Biochem 271: 10351045.

Haraguchi T, Koujin T, Segura-Totten M, Lee KK, Matsuoka Y, Yoneda Y, Wilson KL, Hiraoka Y. 2001. BAF is required for emerin assembly into the reforming nuclear envelope. J Cell Sci 114: 4575-4585.

Harris CA, Andryuk PJ, Cline S, Chan HK, Natarajan A, Siekierka JJ, Goldstein G. 1994. Three distinct human thymopoietins are derived from alternatively spliced mRNAs. Proc Natl Acad Sci 91: 6283-6287.

Hellemans J, Preobrazhenska O, Willaert A, Debeer P, Verdonk PC, Costa T, Janssens K, Menten B, Van Roy N, Vermeulen SJ, et al. 2004. Loss-of-function mutations in LEMD3 result in osteopoikilosis, Buschke-Ollendorff syndrome and melorheostosis. Nat Genet 36: 1213-1218.

Hewett JW, Zeng J, Niland BP, Bragg DC, Breakefield XO. 2006. Dystonia-causing mutant torsinA inhibits cell adhesion and neurite extension through interference with cytoskeletal dynamics. Neurobiol Dis 22: 98-111.

Hirano Y, Segawa M, Ouchi FS, Yamakawa Y, Furukawa K, Takeyasu K, Horigome T. 2005. Dissociation of emerin from barrier-to-autointegration factor is regulated through mitotic phosphorylation of emerin in a Xenopus egg cell-free system. J Biol Chem 280: 39925-39933.

Hodzic DM, Yeater DB, Bengtsson L, Otto H, Stahl PD. 2004. Sun2 is a novel mammalian inner nuclear membrane protein. J Biol Chem 279: 25805-25812.

Hoffmann K, Dreger CK, Olins AL, Olins DE, Shultz LD, Lucke B, Karl H, Kaps R, Muller D, Vaya A, et al. 2002. Mutations in the gene encoding the lamin $\mathrm{B}$ receptor produce an altered nuclear morphology in granulocytes (Pelger-Huet anomaly). Nat Genet 31: 410-414.

Hoffmann K, Sperling K, Olins AL, Olins DE. 2007. The granulocyte nucleus and lamin B receptor: Avoiding the ovoid. Chromosoma 116: 227-235.

Holaska JM, Wilson KL. 2006. Multiple roles for emerin: Implications for Emery-Dreifuss muscular dystrophy. Anat Rec A Discov Mol Cell Evol Biol 288: 676-680.

Holaska JM, Wilson KL. 2007. An emerin "proteome": Purification of distinct emerin-containing complexes from HeLa cells suggests molecular basis for diverse roles including gene regulation, mRNA splicing, signaling, mechanosensing, and nuclear architecture. Biochemistry 46: 8897-8908.

Holaska JM, Kowalski AK, Wilson KL. 2004. Emerin caps the pointed end of actin filaments: Evidence for an actin cortical network at the nuclear inner membrane. PLoS Biol 2: E231.

Holaska JM, Rais-Bahrami S, Wilson KL. 2006. Lmo7 is an emerin-binding protein that regulates the transcription of emerin and many other muscle-relevant genes. Hum Mol Genet 15: 3459-3472.

Holaska JM, Lee KK, Kowalski AK, Wilson KL. 2003. Transcriptional repressor germ cell-less (GCL) and barrier to autointegration factor (BAF) compete for binding to emerin in vitro. J Biol Chem 278: 6969-6975.

Hozak P, Hassan AB, Jackson DA, Cook PR. 1993. Visualization of replication factories attached to nucleoskeleton. Cell 73: 361-373.

Ivorra C, Kubicek M, Gonzalez JM, Sanz-Gonzalez SM, Alvarez-Barrientos A, O'Connor JE, Burke B, Andres V. 2006. A mechanism of AP-1 suppression through interaction of c-Fos with lamin A/C. Genes Dev 20: 307-320.

Jiang X, Xia L, Chen D, Yang Y, Huang H, Yang L, Zhao Q, Shen L, Wang J. 2008. Otefin, a nuclear membrane protein, determines the fate of germline stem cells in Drosophila via interaction with Smad complexes. Dev Cell 14: 494-506.

Johnson BR, Nitta RT, Frock RL, Mounkes L, Barbie DA, Stewart CL, Harlow E, Kennedy BK. 2004. A-type lamins regulate retinoblastoma protein function by promoting subnuclear localization and preventing proteasomal degradation. Proc Natl Acad Sci 101: 9677-9682.

Karst ML, Herron KJ, Olson TM. 2008. X-linked nonsyndromic sinus node dysfunction and atrial fibrillation caused by emerin mutation. J Cardiovasc Electrophysiol 19: $510-515$.

Kracklauer MP, Banks SM, Xie X, Wu Y, Fischer JA. 2007. Drosophila klaroid encodes a SUN domain protein required for Klarsicht localization to the nuclear envelope and nuclear migration in the eye. Fly (Austin) 1: 75-85.

Laguri C, Gilquin B, Wolff N, Romi-Lebrun R, Courchay K, Callebaut I, Worman HJ, Zinn-Justin S. 2001. Structural characterization of the LEM motif common to three human inner nuclear membrane proteins. Structure 9: 503-511.

Lammerding J, Hsiao J, Schulze PC, Kozlov S, Stewart CL, Lee RT. 2005. Abnormal nuclear shape and impaired mechanotransduction in emerin-deficient cells. J Cell Biol 170: 781-791.

Lee KK, Wilson KL. 2004. All in the family: Evidence for four new LEM-domain proteins Lem2 (NET-25), Lem3, Lem4 and Lem5 in the human genome. Symp Soc Exp Biol: 329-339.

Lee KK, Gruenbaum Y, Spann P, Liu J, Wilson KL. 2000. C. elegans nuclear envelope proteins emerin, MAN1, lamin, and nucleoporins reveal unique timing of nuclear envelope breakdown during mitosis. Mol Biol Cell 11: 3089-3099.

Lee KK, Haraguchi T, Lee RS, Koujin T, Hiraoka Y, Wilson KL. 2001. Distinct functional domains in emerin bind lamin A and DNA-bridging protein BAF. J Cell Sci 114: 4567-4573.

Lee KK, Starr D, Cohen M, Liu J, Han M, Wilson KL, Gruenbaum Y. 2002. Lamin-dependent localization of UNC-84, a protein required for nuclear migration in Caenorhabditis elegans. Mol Biol Cell 13: 892-901. 
Li G, Sudlow G, Belmont AS. 1998. Interphase cell cycle dynamics of a late-replicating, heterochromatic homogeneously staining region: Precise choreography of condensation/decondensation and nuclear positioning. J Cell Biol 140: 975-989.

Lin ST, Fu YH. 2009. miR-23 regulation of lamin B1 is crucial for oligodendrocyte development and myelination. Dis Model Mech 2: 178-188.

Lin F, Blake DL, Callebaut I, Skerjanc IS, Holmer L, McBurney MW, Paulin-Levasseur M, Worman HJ. 2000. MAN1, an inner nuclear membrane protein that shares the LEM domain with lamina-associated polypeptide 2 and emerin. J Biol Chem 275: 4840-4847.

Lin F, Morrison JM, Wu W, Worman HJ. 2005. MAN1, an integral protein of the inner nuclear membrane, binds Smad 2 and Smad 3 and antagonizes transforming growth factor- $\beta$ signaling. Hum Mol Genet 14: 437-445.

Liu J, Lee KK, Segura-Totten M, Neufeld E, Wilson KL, Gruenbaum Y. 2003. MAN1 and emerin have overlapping function(s) essential for chromosome segregation and cell division in Caenorhabditis elegans. Proc Natl Acad Sci 100: 4598-4603.

Liu Q, Pante N, Misteli T, Elsagga M, Crisp M, Hodzic D, Burke B, Roux KJ. 2007. Functional association of Sun1 with nuclear pore complexes. J Cell Biol 178: 785-798.

Luderus ME, de Graaf A, Mattia E, den Blaauwen JL, Grande MA, de Jong L, van Driel R. 1992. Binding of matrix attachment regions to lamin B1. Cell 70: 949-959.

Luke Y, Zaim H, Karakesisoglou I, Jaeger VM, Sellin L, Lu W, Schneider M, Neumann S, Beijer A, Munck M, et al. 2008. Nesprin-2 Giant (NUANCE) maintains nuclear envelope architecture and composition in skin. J Cell Sci 121: 1887-1898.

Luo Y, Yang C, Jin C, Xie R, Wang F, McKeehan WL. 2009. Novel phosphotyrosine targets of FGFR2IIIb signaling. Cell Signal 21: 1370-1378.

Makatsori D, Kourmouli N, Polioudaki H, Shultz LD, McLean K, Theodoropoulos PA, Singh PB, Georgatos SD. 2004. The inner nuclear membrane protein lamin $\mathrm{B}$ receptor forms distinct microdomains and links epigenetically marked chromatin to the nuclear envelope. $J$ Biol Chem 279: 25567-25573.

Malhas AN, Lee CF, Vaux DJ. 2009. Lamin B1 controls oxidative stress responses via Oct-1. J Cell Biol 184: $45-55$.

Malone CJ, Fixsen WD, Horvitz HR, Han M. 1999. UNC-84 localizes to the nuclear envelope and is required for nuclear migration and anchoring during C. elegans development. Development 126: 3171-3181.

Malone CJ, Misner L, Le Bot N, Tsai MC, Campbell JM, Ahringer J, White JG. 2003. The C. elegans hook protein, ZYG-12, mediates the essential attachment between the centrosome and nucleus. Cell 115: 825-836.

Manilal S, Nguyen TM, Sewry CA, Morris GE. 1996. The Emery-Dreifuss muscular dystrophy protein, emerin, is a nuclear membrane protein. Hum Mol Genet 5: 801808.

Mansharamani M, Wilson KL. 2005. Direct binding of nuclear membrane protein MAN1 to emerin in vitro and two modes of binding to barrier-to-autointegration factor. J Biol Chem 280: 13863-13870.
Margalit A, Brachner A, Gotzmann J, Foisner R, Gruenbaum Y. 2007. Barrier-to-autointegration factor-a BAFfling little protein. Trends Cell Biol 17: 202-208.

Margalit A, Segura-Totten M, Gruenbaum Y, Wilson KL. 2005a. Barrier-to-autointegration factor is required to segregate and enclose chromosomes within the nuclear envelope and assemble the nuclear lamina. Proc Natl Acad Sci 102: 3290-3295.

Margalit A, Vlcek S, Gruenbaum Y, Foisner R. 2005b. Breaking and making of the nuclear envelope. J Cell Biochem 95: $454-465$.

Mariappan I, Gurung R, Thanumalayan S, Parnaik VK. 2007. Identification of cyclin D3 as a new interaction partner of lamin A/C. Biochem Biophys Res Commun 355: 981-985.

Markiewicz E, Dechat T, Foisner R, Quinlan RA, Hutchison CJ. 2002. Lamin A/C binding protein LAP2 $\alpha$ is required for nuclear anchorage of retinoblastoma protein. $\mathrm{Mol}$ Biol Cell 13: 4401-4413.

Markiewicz E, Tilgner K, Barker N, van de Wetering M, Clevers H, Dorobek M, Hausmanowa-Petrusewicz I, Ramaekers FC, Broers JL, Blankesteijn WM, et al. 2006. The inner nuclear membrane protein emerin regulates $\beta$-catenin activity by restricting its accumulation in the nucleus. EMBO J 25: 3275-3285.

Martin L, Crimaudo C, Gerace L. 1995. cDNA cloning and characterization of lamina-associated polypeptide 1C (LAP1C), an integral protein of the inner nuclear membrane. J Biol Chem 270: 8822-8828.

Martins S, Eikvar S, Furukawa K, Collas P. 2003. HA95 and LAP2 $\beta$ mediate a novel chromatin-nuclear envelope interaction implicated in initiation of DNA replication. $J$ Cell Biol 160: 177-188.

Mattout A, Goldberg M, Tzur Y, Margalit A, Gruenbaum Y. 2007. Specific and conserved sequences in D. melanogaster and C. elegans lamins and histone H2A mediate the attachment of lamins to chromosomes. J Cell Sci 120: 77-85.

McGee MD, Rillo R, Anderson AS, Starr DA. 2006. UNC-83 is a KASH protein required for nuclear migration and is recruited to the outer nuclear membrane by a physical interaction with the SUN protein UNC-84. Mol Biol Cell 17: 1790-1801.

Mejat A, Decostre V, Li J, Renou L, Kesari A, Hantai D, Stewart CL, Xiao X, Hoffman E, Bonne G, et al. 2009. Lamin A/ $\mathrm{C}$-mediated neuromuscular junction defects in EmeryDreifuss muscular dystrophy. J Cell Biol 184: 31-44.

Melcon G, Kozlov S, Cutler DA, Sullivan T, Hernandez L, Zhao P, Mitchell S, Nader G, Bakay M, Rottman JN, et al. 2006. Loss of emerin at the nuclear envelope disrupts the Rb1/E2F and MyoD pathways during muscle regeneration. Hum Mol Genet 15: 637-651.

Mislow JM, Holaska JM, Kim MS, Lee KK, Segura-Totten M, Wilson KL, McNally EM. 2002a. Nesprin-1 $\alpha$ self-associates and binds directly to emerin and lamin A in vitro. FEBS Lett 525: 135-140.

Mislow JM, Kim MS, Davis DB, McNally EM. 2002b. Myne-1, a spectrin repeat transmembrane protein of the myocyte inner nuclear membrane, interacts with lamin A/C. J Cell Sci 115: 61-70.

Moir RD, Spann TP, Herrmann H, Goldman RD. 2000a. Disruption of nuclear lamin organization blocks the 
elongation phase of DNA replication. J Cell Biol 149: 1179-1192.

Moir RD, Yoon M, Khuon S, Goldman RD. 2000b. Nuclear lamins A and B1: different pathways of assembly during nuclear envelope formation in living cells. J Cell Biol 151: $1155-1168$

Muchir A, Pavlidis P, Bonne G, Hayashi YK, Worman HJ. 2007. Activation of MAPK in hearts of EMD null mice: Similarities between mouse models of X-linked and autosomal dominant Emery Dreifuss muscular dystrophy. Hum Mol Genet 16: 1884-1895.

Muchir A, Shan J, Bonne G, Lehnart SE, Worman HJ. 2009. Inhibition of extracellular signal-regulated kinase signaling to prevent cardiomyopathy caused by mutation in the gene encoding A-type lamins. Hum Mol Genet 18: 241-247.

Naetar N, Hutter S, Dorner D, Dechat T, Korbei B, Gotzmann J, Beug H, Foisner R. 2007. LAP2 $\alpha$-binding protein LINT-25 is a novel chromatin-associated protein involved in cell cycle exit. J Cell Sci 120: 737-747.

Naetar N, Korbei B, Kozlov S, Kerenyi MA, Dorner D, Kral R, Gotic I, Fuchs P, Cohen TV, Bittner R, et al. 2008. Loss of nucleoplasmic LAP2 $\alpha$-lamin A complexes causes erythroid and epidermal progenitor hyperproliferation. Nat Cell Biol 10: 1341-1348.

Naismith TV, Heuser JE, Breakefield XO, Hanson PI. 2004 TorsinA in the nuclear envelope. Proc Natl Acad Sci 101: 7612-7617.

Nery FC, Zeng J, Niland BP, Hewett J, Farley J, Irimia D, Li Y, Wiche G, Sonnenberg A, Breakefield XO. 2008. TorsinA binds the KASH domain of nesprins and participates in linkage between nuclear envelope and cytoskeleton. $J$ Cell Sci 121: 3476-3486.

Nili E, Cojocaru GS, Kalma Y, Ginsberg D, Copeland NG, Gilbert DJ, Jenkins NA, Berger R, Shaklai S, Amariglio $\mathrm{N}$, et al. 2001. Nuclear membrane protein LAP2 $\beta$ mediates transcriptional repression alone and together with its binding partner GCL (germ-cell-less). J Cell Sci 114: 3297-3307.

Nitta RT, Smith CL, Kennedy BK. 2007. Evidence that proteasome-dependent degradation of the retinoblastoma protein in cells lacking A-type lamins occurs independently of gankyrin and MDM2. PLOS ONE 2: e963.

Nitta RT, Jameson SA, Kudlow BA, Conlan LA, Kennedy BK. 2006. Stabilization of the retinoblastoma protein by A-type nuclear lamins is required for INK4A-mediated cell cycle arrest. Mol Cell Biol 26: 5360-5372.

Osada S, Ohmori SY, Taira M. 2003. XMAN1, an inner nuclear membrane protein, antagonizes BMP signaling by interacting with Smad1 in Xenopus embryos. Development 130: 1783-1794.

Ottaviani A, Rival-Gervier S, Boussouar A, Foerster AM, Rondier D, Sacconi S, Desnuelle C, Gilson E, Magdinier F. 2009. The D4Z4 macrosatellite repeat acts as a CTCF and A-type lamins-dependent insulator in facioscapulo-humeral dystrophy. PLoS Genet 5: e1000394.

Ozaki T, Saijo M, Murakami K, Enomoto H, Taya Y, Sakiyama S. 1994. Complex formation between lamin A and the retinoblastoma gene product: Identification of the domain on lamin A required for its interaction. Oncogene 9: $2649-2653$.
Ozawa R, Hayashi YK, Ogawa M, Kurokawa R, Matsumoto H, Noguchi S, Nonaka I, Nishino I. 2006. Emerinlacking mice show minimal motor and cardiac dysfunctions with nuclear-associated vacuoles. Am J Patho 168: 907-917.

Padiath QS, Saigoh K, Schiffmann R, Asahara H, Yamada T, Koeppen A, Hogan K, Ptacek LJ, Fu YH. 2006. Lamin B1 duplications cause autosomal dominant leukodystrophy. Nat Genet 38: 1114-1123.

Padmakumar VC, Abraham S, Braune S, Noegel AA, Tunggal B, Karakesisoglou I, Korenbaum E. 2004. Enaptin, a giant actin-binding protein, is an element of the nuclear membrane and the actin cytoskeleton. Exp Cell Res 295: $330-339$.

Padmakumar VC, Libotte T, Lu W, Zaim H, Abraham S, Noegel AA, Gotzmann J, Foisner R, Karakesisoglou I. 2005. The inner nuclear membrane protein Sunl mediates the anchorage of Nesprin-2 to the nuclear envelope. J Cell Sci 118: 3419-3430.

Pan D, Estevez-Salmeron LD, Stroschein SL, Zhu X, He J, Zhou S, Luo K. 2005. The integral inner nuclear membrane protein MAN1 physically interacts with the $\mathrm{R}$-Smad proteins to repress signaling by the transforming growth factor- $\beta$ superfamily of cytokines. J Biol Chem 280: 15992-16001.

Park YE, Hayashi YK, Bonne G, Arimura T, Noguchi S, Nonaka I, Nishino I. 2009a. Autophagic degradation of nuclear components in mammalian cells. Autophagy 5: 795-804.

Park YE, Hayashi YK, Goto K, Komaki H, Hayashi Y, Inuzuka T, Noguchi S, Nonaka I, Nishino I. 2009b. Nuclear changes in skeletal muscle extend to satellite cells in autosomal dominant Emery-Dreifuss muscular dystrophy/ limb-girdle muscular dystrophy 1B. Neuromuscul Disord 19: $29-36$

Patterson K, Molofsky AB, Robinson C, Acosta S, Cater C, Fischer JA. 2004. The functions of Klarsicht and nuclear lamin in developmentally regulated nuclear migrations of photoreceptor cells in the Drosophila eye. Mol Biol Cell 15: 600-610.

Pekovic V, Harborth J, Broers JL, Ramaekers FC, van Engelen B, Lammens M, von Zglinicki T, Foisner R, Hutchison C, Markiewicz E. 2007. Nucleoplasmic LAP2 $\alpha$-lamin A complexes are required to maintain a proliferative state in human fibroblasts. J Cell Biol 176: $163-172$.

Penkner A, Tang L, Novatchkova M, Ladurner M, Fridkin A, Gruenbaum Y, Schweizer D, Loidl J, Jantsch V. 2007. The nuclear envelope protein Matefin/SUN-1 is required for homologous pairing in C. elegans meiosis. Dev Cell 12: 873-885.

Pickersgill H, Kalverda B, de Wit E, Talhout W, Fornerod M, van Steensel B. 2006. Characterization of the Drosophila melanogaster genome at the nuclear lamina. Nat Genet 38: $1005-1014$.

Polioudaki H, Kourmouli N, Drosou V, Bakou A, Theodoropoulos PA, Singh PB, Giannakouros T, Georgatos SD. 2001. Histones H3/H4 form a tight complex with the inner nuclear membrane protein LBR and heterochromatin protein 1. EMBO Rep 2: 920-925.

Puckelwartz MJ, Kessler E, Zhang Y, Hodzic D, Randles KN, Morris G, Earley JU, Hadhazy M, Holaska JM, Mewborn 
SK, et al. 2009. Disruption of nesprin-1 produces an Emery Dreifuss muscular dystrophy-like phenotype in mice. Hum Mol Genet 18: 607-620.

Raju GP, Dimova N, Klein PS, Huang HC. 2003. SANE, a novel LEM domain protein, regulates bone morphogenetic protein signaling through interaction with Smad1. J Biol Chem 278: 428-437.

Roberts RC, Sutherland-Smith AJ, Wheeler MA, Jensen ON Emerson LJ, Spiliotis II, Tate CG, Kendrick-Jones J, Ellis JA. 2006. The Emery-Dreifuss muscular dystrophy associated-protein emerin is phosphorylated on serine 49 by protein kinase A. Febs J 273: 4562-4575.

Roux KJ, Crisp ML, Liu Q, Kim D, Kozlov S, Stewart CL, Burke B. 2009. Nesprin 4 is an outer nuclear membrane protein that can induce kinesin-mediated cell polarization. Proc Natl Acad Sci 106: 2194-2199.

Sabatelli P, Lattanzi G, Ognibene A, Columbaro M, Capanni C, Merlini L, Maraldi NM, Squarzoni S. 2001. Nuclear alterations in autosomal-dominant Emery-Dreifuss muscular dystrophy. Muscle Nerve 24: 826-829.

Sakaki M, Koike H, Takahashi N, Sasagawa N, Tomioka S, Arahata K, Ishiura S. 2001. Interaction between emerin and nuclear lamins. J. Biochem 129: 321-327.

Salpingidou G, Smertenko A, Hausmanowa-Petrucewicz I, Hussey PJ, Hutchison CJ. 2007. A novel role for the nuclear membrane protein emerin in association of the centrosome to the outer nuclear membrane. J Cell Biol 178: 897-904.

Scaffidi P, Misteli T. 2006. Lamin A-dependent nuclear defects in human aging. Science 312: 1059-1063.

Scaffidi P, Misteli T. 2008. Lamin A-dependent misregulation of adult stem cells associated with accelerated ageing. Nat Cell Biol 10: 452-459.

Schirmer EC, Foisner R. 2007. Proteins that associate with lamins: Many faces, many functions. Exp Cell Res 313: 2167-2179.

Schirmer EC, Gerace L. 2005. The nuclear membrane proteome: Extending the envelope. Trends Biochem Sci 30: 551-558.

Schirmer EC, Florens L, Guan T, Yates JR 3rd, Gerace L. 2003. Nuclear membrane proteins with potential disease links found by subtractive proteomics. Science 301: 1380-1382.

Schirmer EC, Florens L, Guan T, Yates JR 3rd, Gerace L. 2005. Identification of novel integral membrane proteins of the nuclear envelope with potential disease links using subtractive proteomics. Novartis Found. Symp 264: 63-76; discussion 76-80, 227-230.

Schlosser A, Amanchy R, Otto H. 2006. Identification of tyrosine-phosphorylation sites in the nuclear membrane protein emerin. FEBS J 273: 3204-3215.

Schmitt J, Benavente R, Hodzic D, Hoog C, Stewart CL, Alsheimer M. 2007. Transmembrane protein Sun2 is involved in tethering mammalian meiotic telomeres to the nuclear envelope. Proc Natl Acad Sci 104: 7426-7431.

Senior A, Gerace L. 1988. Integral membrane proteins specific to the inner nuclear membrane and associated with the nuclear lamina. J Cell Biol 107: 2029-2036.

Shimi T, Koujin T, Segura-Totten M, Wilson KL, Haraguchi T, Hiraoka Y. 2004. Dynamic interaction between BAF and emerin revealed by FRAP, FLIP, and FRET analyses in living HeLa cells. J Struct Biol 147: 31-41.

Shoeman RL, Traub P. 1990. The in vitro DNA-binding properties of purified nuclear lamin proteins and vimentin. J Biol Chem 265: 9055-9061.

Shumaker DK, Dechat T, Kohlmaier A, Adam SA, Bozovsky MR, Erdos MR, Eriksson M, Goldman AE, Khuon S, Collins FS, et al. 2006. Mutant nuclear lamin A leads to progressive alterations of epigenetic control in premature aging. Proc Natl Acad Sci 103: 8703-8708.

Shumaker DK, Lee KK, Tanhehco YC, Craigie R, Wilson KL. 2001. LAP2 binds to BAF.DNA complexes: requirement for the LEM domain and modulation by variable regions. EMBO J 20: 1754-1764

Shumaker DK, Solimando L, Sengupta K, Shimi T, Adam SA, Grunwald A, Strelkov SV, Aebi U, Cardoso MC, Goldman RD. 2008. The highly conserved nuclear lamin Ig-fold binds to PCNA: Its role in DNA replication. $J$ Cell Biol 181: 269-280.

Somech R, Shaklai S, Geller O, Amariglio N, Simon AJ, Rechavi G, Gal-Yam EN. 2005. The nuclear-envelope protein and transcriptional repressor LAP $2 \beta$ interacts with HDAC3 at the nuclear periphery, and induces histone H4 deacetylation. J Cell Sci 118: 4017-4025.

Spann TP, Moir RD, Goldman AE, Stick R, Goldman RD. 1997. Disruption of nuclear lamin organization alters the distribution of replication factors and inhibits DNA synthesis. J Cell Biol 136: 1201-1212.

Starr DA. 2009. A nuclear-envelope bridge positions nuclei and moves chromosomes. J Cell Sci 122: 577-586.

Starr DA, Fischer JA. 2005. KASH 'n Karry: The KASH domain family of cargo-specific cytoskeletal adaptor proteins. Bioessays 27: 1136-1146.

Starr DA, Han M. 2002. Role of ANC-1 in tethering nuclei to the actin cytoskeleton. Science 298: 406-409.

Starr DA, Hermann GJ, Malone CJ, Fixsen W, Priess JR, Horvitz HR, Han M. 2001. unc-83 encodes a novel component of the nuclear envelope and is essential for proper nuclear migration. Development 128: 5039-5050.

Stewart CL, Roux KJ, Burke B. 2007. Blurring the boundary: The nuclear envelope extends its reach. Science 318: $1408-1412$.

Stewart-Hutchinson PJ, Hale CM, Wirtz D, Hodzic D. 2008. Structural requirements for the assembly of LINC complexes and their function in cellular mechanical stiffness. Exp Cell Res 314: 1892-1905.

Stierle V, Couprie J, Ostlund C, Krimm I, Zinn-Justin S, Hossenlopp P, Worman HJ, Courvalin JC, DubandGoulet I. 2003. The carboxyl-terminal region common to lamins $\mathrm{A}$ and $\mathrm{C}$ contains a DNA binding domain. Biochemistry 42: 4819-4828.

Sullivan T, Escalante-Alcalde D, Bhatt H, Anver M, Bhat N, Nagashima K, Stewart CL, Burke B. 1999. Loss of A-type lamin expression compromises nuclear envelope integrity leading to muscular dystrophy. J Cell Biol 147: 913-920.

Tang K, Finley RL Jr, Nie D, Honn KV. 2000. Identification of 12-lipoxygenase interaction with cellular proteins by yeast two-hybrid screening. Biochemistry 39: 3185-3191. 
Taniura H, Glass C, Gerace L. 1995. A chromatin binding site in the tail domain of nuclear lamins that interacts with core histones. J Cell Biol 131: 33-44.

Taylor MR, Slavov D, Gajewski A, Vlcek S, Ku L, Fain PR, Carniel E, Di Lenarda A, Sinagra G, Boucek MM, et al. 2005. Thymopoietin (lamina-associated polypeptide 2) gene mutation associated with dilated cardiomyopathy. Hum Mutat 26: 566-574.

Tifft KE, Bradbury KA, Wilson KL. 2009. Tyrosine phosphorylation of nuclear-membrane protein emerin by Src, Abl and other kinases. J Cell Sci 122: 3780-3790.

Tilgner K, Wojciechowicz K, Jahoda C, Hutchison C, Markiewicz E. 2009. Dynamic complexes of A-type lamins and emerin influence adipogenic capacity of the cell via nucleocytoplasmic distribution of $\beta$-catenin. J Cell Sci 122: 401-413.

Tzur YB, Wilson KL, Gruenbaum Y. 2006b. SUN-domain proteins: 'Velcro' that links the nucleoskeleton to the cytoskeleton. Nat Rev Mol Cell Biol 7: 782-788.

Tzur YB, Margalit A, Melamed-Book N, Gruenbaum Y. 2006a. Matefin/SUN-1 is a nuclear envelope receptor for CED-4 during Caenorhabditis elegans apoptosis. Proc Natl Acad Sci 103: 13397-13402.

Ulbert S, Antonin W, Platani M, Mattaj IW. 2006. The inner nuclear membrane protein Lem2 is critical for normal nuclear envelope morphology. FEBS Lett 580: 64356441.

Ura S, Hayashi YK, Goto K, Astejada MN, Murakami T, Nagato M, Ohta S, Daimon Y, Takekawa H, Hirata K, et al. 2007. Limb-girdle muscular dystrophy due to emerin gene mutations. Arch Neurol 64: 1038-1041.

Van Berlo JH, Voncken JW, Kubben N, Broers JL, Duisters R, van Leeuwen RE, Crijns HJ, Ramaekers FC, Hutchison CJ, Pinto YM. 2005. A-type lamins are essential for TGF- $\beta 1$ induced PP2A to dephosphorylate transcription factors. Hum Mol Genet 14: 2839-2849.

Vaughan A, Alvarez-Reyes M, Bridger JM, Broers JL, Ramaekers FC, Wehnert M, Morris GE, Whitfield WGF, Hutchison CJ. 2001. Both emerin and lamin C depend on lamin A for localization at the nuclear envelope. J Cell Sci 114: 2577-2590.

Vlcek S, Foisner R. 2007. A-type lamin networks in light of laminopathic diseases. Biochim Biophys Acta 1773: 661-674.

Vlcek S, Foisner R, Wilson KL. 2004. Lco1 is a novel widely expressed lamin-binding protein in the nuclear interior. Exp Cell Res 298: 499-511.

Vlcek S, Korbei B, Foisner R. 2002. Distinct functions of the unique $\mathrm{C}$ terminus of LAP2 $\alpha$ in cell proliferation and nuclear assembly. J Biol Chem 277: 18898-18907.

Wagner N, Krohne G. 2007. LEM-Domain proteins: New insights into lamin-interacting proteins. Int Rev Cytol 261: 1-46.

Wagner N, Schmitt J, Krohne G. 2004. Two novel LEMdomain proteins are splice products of the annotated Drosophila melanogaster gene CG9424 (Bocksbeutel). Eur J Cell Biol 82: 605-616.

Wagner N, Kagermeier B, Loserth S, Krohne G. 2006. The Drosophila melanogaster LEM-domain protein MAN1. Eur J Cell Biol 85: 91-105.
Wang Y, Herron AJ, Worman HJ. 2006. Pathology and nuclear abnormalities in hearts of transgenic mice expressing M371K lamin A encoded by an LMNA mutation causing Emery-Dreifuss muscular dystrophy. Hum $\mathrm{Mol}$ Genet 15: 2479-2489.

Waterham HR, Koster J, Mooyer P, Noort Gv G, Kelley RI, Wilcox WR, Wanders RJ, Hennekam RC, Oosterwijk JC. 2003. Autosomal recessive HEM/Greenberg skeletal dysplasia is caused by $3 \beta$-hydroxysterol delta 14-reductase deficiency due to mutations in the lamin B receptor gene. Am J Hum Genet 72: 1013-1017.

Wheeler MA, Davies JD, Zhang Q, Emerson LJ, Hunt J, Shanahan CM, Ellis JA. 2007. Distinct functional domains in nesprin- $1 \alpha$ and nesprin- $2 \beta$ bind directly to emerin and both interactions are disrupted in X-linked Emery-Dreifuss muscular dystrophy. Exp Cell Res 313: 2845-2857.

Wilhelmsen K, Ketema M, Truong H, Sonnenberg A. 2006. $\mathrm{KASH}$-domain proteins in nuclear migration, anchorage and other processes. J Cell Sci 119: 5021-5029.

Wilhelmsen K, Litjens SH, Kuikman I, Tshimbalanga N, Janssen H, van den Bout I, Raymond K, Sonnenberg A. 2005. Nesprin-3, a novel outer nuclear membrane protein, associates with the cytoskeletal linker protein plectin. J Cell Biol 171: 799-810.

Worman HJ, Bonne G. 2007. "Laminopathies": A wide spectrum of human diseases. Exp Cell Res 313: 2121-2133.

Worman HJ, Evans CD, Blobel G. 1990. The lamin B receptor of the nuclear envelope inner membrane: A polytopic protein with eight potential transmembrane domains. J Cell Biol 111: 1535-1542.

Worman HJ, Yuan J, Blobel G, Georgatos SD. 1988. A lamin $\mathrm{B}$ receptor in the nuclear envelope. Proc Natl Acad Sci 85: 8531-8534.

Xie X, Fischer JA. 2008. On the roles of the Drosophila KASH domain proteins Msp-300 and Klarsicht. Fly 2: $74-81$.

Ye Q, Worman HJ. 1996. Interaction between an integral protein of the nuclear envelope inner membrane and human chromodomain proteins homologous to Drosophila HP1. J Biol Chem 271: 14653-14656.

Zastrow MS, Vlcek S, Wilson KL. 2004. Proteins that bind A-type lamins: Integrating isolated clues. J Cell Sci 117: 979-987.

Zhang Q, Ragnauth CD, Skepper JN, Worth NF, Warren DT, Roberts RG, Weissberg PL, Ellis JA, Shanahan CM. 2005. Nesprin-2 is a multi-isomeric protein that binds lamin and emerin at the nuclear envelope and forms a subcellular network in skeletal muscle. J Cell Sci 118: 673-687.

Zhang Q, Skepper JN, Yang F, Davies JD, Hegyi L, Roberts RG, Weissberg PL, Ellis JA, Shanahan CM. 2001. Nesprins: A novel family of spectrin-repeat-containing proteins that localize to the nuclear membrane in multiple tissues. J Cell Sci 114: 4485-4498.

Zhang X, Xu R, Zhu B, Yang X, Ding X, Duan S, Xu T, Zhuang Y, Han M. 2007. Syne-1 and Syne-2 play crucial roles in myonuclear anchorage and motor neuron innervation. Development 134: 901-908.

Zhen YY, Libotte T, Munck M, Noegel AA, Korenbaum E. 2002. NUANCE, a giant protein connecting the nucleus and actin cytoskeleton. J Cell Sci 115: 3207-3222. 


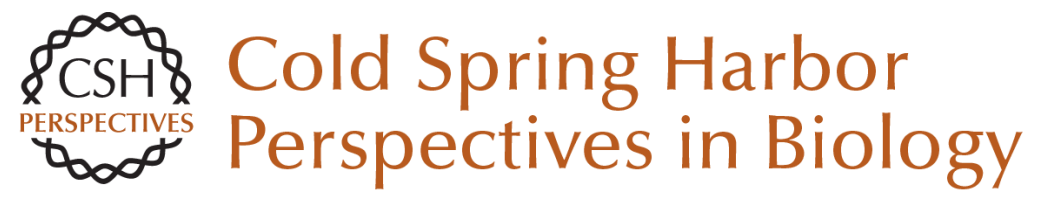

\section{Lamin-binding Proteins}

Katherine L. Wilson and Roland Foisner

Cold Spring Harb Perspect Biol 2010; doi: 10.1101/cshperspect.a000554 originally published online February 17, 2010

\section{Subject Collection The Nucleus}

Nuclear Compartments: An Incomplete Primer to Nuclear Compartments, Bodies, and Genome Organization Relative to Nuclear Architecture Andrew S. Belmont

Uncovering the Principles of Genome Folding by 3D Chromatin Modeling

Asli Yildirim, Lorenzo Boninsegna, Yuxiang Zhan, et al.

3D or Not 3D: Shaping the Genome during Development Juliane Glaser and Stefan Mundlos

The Impact of Space and Time on the Functional Output of the Genome Marcelo Nollmann, Isma Bennabi, Markus Götz, et al.

Chromatin Mechanisms Driving Cancer Berkley Gryder, Peter C. Scacheri, Thomas Ried, et al.

Liquid-Liquid Phase Separation in Chromatin Karsten Rippe

Mechanical Forces in Nuclear Organization Yekaterina A. Miroshnikova and Sara A. Wickström

Imaging Organization of RNA Processing within the Nucleus

Jeetayu Biswas, Weihan Li, Robert H. Singer, et al.
Mechanisms of Chromosome Folding and Nuclear Organization: Their Interplay and Open Questions Leonid Mirny and Job Dekker

Epigenetic Reprogramming in Early Animal Development

Zhenhai Du, Ke Zhang and Wei Xie

Essential Roles for RNA in Shaping Nuclear Organization

Sofia A. Quinodoz and Mitchell Guttman

The Molecular and Nuclear Dynamics of

$\mathrm{X}$-Chromosome Inactivation

François Dossin and Edith Heard

Structure, Maintenance, and Regulation of

Nuclear Pore Complexes: The Gatekeepers of the

Eukaryotic Genome Marcela Raices and Maximiliano A. D'Angelo

The Nuclear Lamina Xianrong Wong, Ashley J. Melendez-Perez and Karen L. Reddy

The Nuclear Pore Complex as a Transcription Regulator Michael Chas Sumner and Jason Brickner

Physical Nature of Chromatin in the Nucleus Kazuhiro Maeshima, Shiori lida and Sachiko Tamura

For additional articles in this collection, see http://cshperspectives.cshlp.org/cgi/collection/

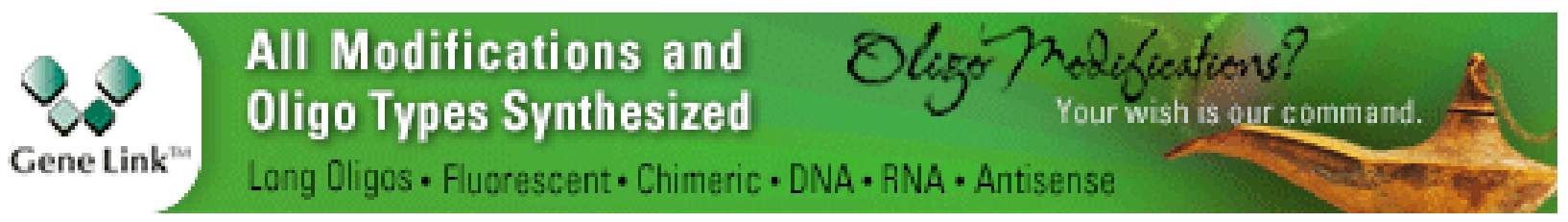


For additional articles in this collection, see http://cshperspectives.cshlp.org/cgi/collection/

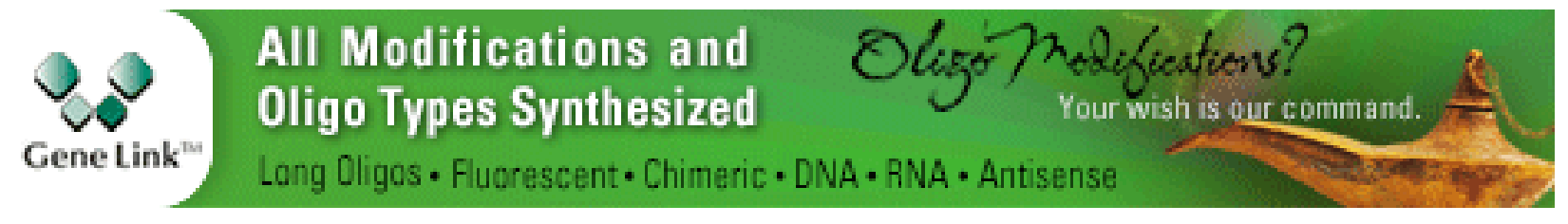

Copyright @ 2010 Cold Spring Harbor Laboratory Press; all rights reserved 